\title{
免疫系の老化と慢性炎症
}

内藤篤彦*

\section{Aging of the immune system and chronic inflammation}

\author{
Atsuhiko NAITO
}

要約 : 個体老化とは「加齢に伴い死亡率が増加する原因となる様々な臟器の機能低下」と定義される生命現象 である，加齢に伴って免疫系が老化する結果，免疫系本来の非自己を排除する機構と炎症反応を制御する機 構が低下し，高齢者で認められる易感染性や慢性炎症が引き起こされる，補体分子 $\mathrm{C} 1 \mathrm{q}$ は自然免疫系におい て重要な役割を果たす因子であり，免疫系の老化が引き起こす慢性炎症に伴って血中濃度が増加することが 知られているが, われわれは C1q が補体経路非依存性に加齢に伴う骨格筋の再生能低下という老化現象の原 因になっていることを報告している. 本稿では前半に加齢に伴う免疫系の老化現象について概説し, 後半で は補体分子 $\mathrm{Clq}$ による老化誘導のメカニズムについて述べる.

Key words: 老化, immunosenescence, inflammaging, C1q, Wnt シグナル

\section{1. 免疫系の老化}

加齢に伴って個体の生存に必要な様々な生命機能 が低下していく現象を「老化」とよんでいる，加齢に 伴う免疫系の变化，すなわち免疫系の老化を特徵つ ける現象として“Immunosenescence”と “Inflammaging” が挙げられる(図 1)，前者は免疫系本来の非自己を 排除する機構が加齢に伴って低下することを指し， 高齢者で認められる易感染性の原因となっている. 後者は炎症反応を制御する機構が加齢に伴って低下 する結果，慢性的に低レベルの炎症が持続する現象 を指し，高齢者で認められる自己抗体の保有率や血 中の炎症性物質, 慢性炎症が病態に深く関与する疾 患の発症率が増加する原因となっている。

\section{Immunosenescence}

免疫系には, 多核球や単球由来細胞などの貪食系 細胞が非特異的に病原体・非自己を排除するメカニ ズムである「自然免疫系」と, リンパ球が抗原特異的 に強い免疫反応を引き起こす「獲得免疫系」が存在す

\footnotetext{
*責任者連絡先：

東京大学医学部附属病院

干 113-8655 東京都文京区 7-3-1

Tel: 03-3815-5411

E-mail: at-naito@umin.ac.jp
}

る。単球由来細胞であるマクロファージや樹状細胞 はリンパ球に抗原を提示することで獲得免疫系を活 性化させ，協調して非自己の判断とその排除を行っ ている，老化に伴い，自然免疫系では領食系細胞に よる非自己の荟食·分解および抗原提示能低下や ${ }^{1,2)}$,

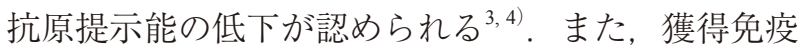
系で起こる老化現象として， Tリンパ球の量的・質 的な異常が挙げられる ${ }^{5,6)}$. $\mathrm{T}$ リンパ球には抗原曝露 を受けていないナイーヴ Tリンパ球と，抗原の提示 を受け活性化された後に休眠状態にあるメモリーT リンパ球の 2 種類が存在するが, 加齢に伴って胸腺 からのナイーヴ Tリンパ球の産生が減少する結果, 新たな非自己に対する反応性が低下する ${ }^{7,8)}$. また, 加齢に伴って抗原提示を受けても正しい免疫シナプ スを形成することができず9)，適切に活性化されな いことが報告されている ${ }^{10)}$ (図 2).

\section{Inflammaging}

加齢に伴って免疫機能は個体・細胞レベルで低下 しているが，一方で高齢者の血中において Interleukin-6(IL-6) ${ }^{11)}$ や Tumor Necrosis Factor alpha $(\mathrm{TNFa})^{12)}$ などの炎症性サイトカイン, C-reactive protein (CRP $)^{11)}$ や種々の補体分子 ${ }^{13)}$ といった炎症性タンパクが慢性 的に増加している。免疫機能の低下と慢性炎症の卉 進は一見矛盾する現象のように考えられるが，苓食 
細胞内の殺菌能が低下する慢性肉芽腫症 14 や CD18 を介した貪食細胞の機能が低下する Leukocyte Adhesion Deficiency15 といった遺伝性の免疫不全疾患, Human Immunodeficiency Virus (HIV) 感染 ${ }^{16)}$ にる後 天性の免疫不全でも慢性炎症像が認められることか ら，免疫機能低下と慢性炎症は老化に限らず普遍的 に認められる表裏一体の現象であると考えられる。

免疫機能低下と慢性炎症反応との因果関係は分子 レベルでは明らかにされていないが，個体レベルで 免疫機能低下が継続することに伴う持続的な感染, とくにサイトメガロウイルスや EB ウイルスといっ た一般的なウイルスの不顕性感染が，マクロファー ジを中心とした単球系細胞の持続的な免疫応答と炎

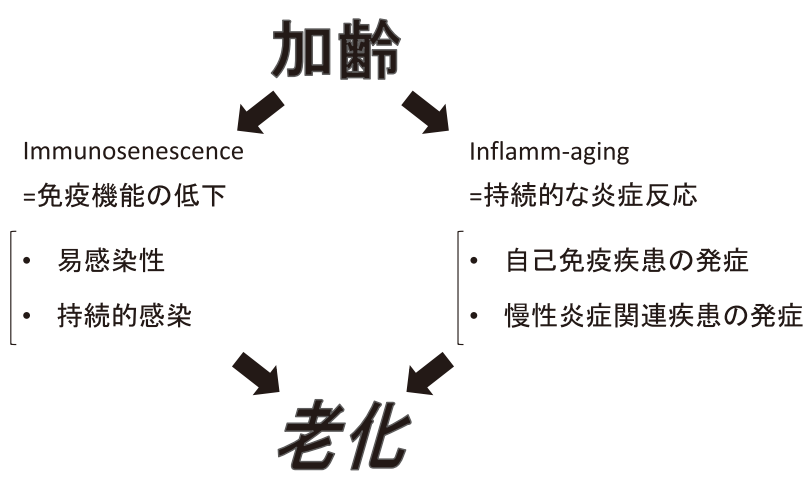

図 1 免疫系の老化

加齢に伴って, 免疫機能の中で非自己を排除する機能が 低下寸る結果，感染症への罹患率が増加する，持続的な 感染は持続的な炎症反応を引き起こし, 自己免疫疾患や 慢性炎症関連疾患を発症させる。
症性サイトカインの持続的分泌を引き起こすことが 原因の一つと考えられている ${ }^{17,18)}$ 。 また, 単球系細 胞が引き起こす炎症反応は組織障害を介してさらな る炎症応答を誘導するとともに, リンパ球のレパー トアをさらに減少させて免疫機能を低下させる原因 ともなっており，悪循環によって免疫機能の変化が 加齢によって加速していくのではないかと考えられ る(図 3)。

\section{2. 老化と補体分子 C1q}

\section{自然免疫系における補体分子 C1q}

自然免疫系では非自己を認識する原始的な受容体 (PRPs: Pattern Recognition Receptors) として, (1)補体 分子やマンノース結合レクチン $(\mathrm{MBL})$ などの分泌型 PRRs, (2)スカベンジャー受容体といった病原体など の取り达みに関与する PRRs，(3) TLR ファミリーに 代表されるシグナル伝達経路を活性化させる PRRs, の 3 つが存在する. 補体分子 C1q は分泌型の PRRs に分類され，自然免疫系に抢いて古典的補体経路の 活性化や，領食作用の促進に重要な役割を果たす。

$\mathrm{C} 1 \mathrm{q}$ は $\mathrm{C} 1 \mathrm{r}, \mathrm{C} 1 \mathrm{~s}$ と共に $\mathrm{C} 1$ 複合体を形成する。 $\mathrm{C} 1$ 複合体中の $\mathrm{C} 1 \mathrm{q}$ が病原体と結合することで $\mathrm{C} 1$ 複合 体の立体構造が変化し，プロテアーゼ $\mathrm{C} 1 \mathrm{r} ， \mathrm{C} 1 \mathrm{~s}$ の 自己活性化を誘導され, 活性化 $\mathrm{C} 1 \mathrm{~s}$ が下流の補体 分子である C4，C2 を分解することで補体経路の卜 リガーがひかれる ${ }^{19)}$. C1q には病原体と結合し, 古

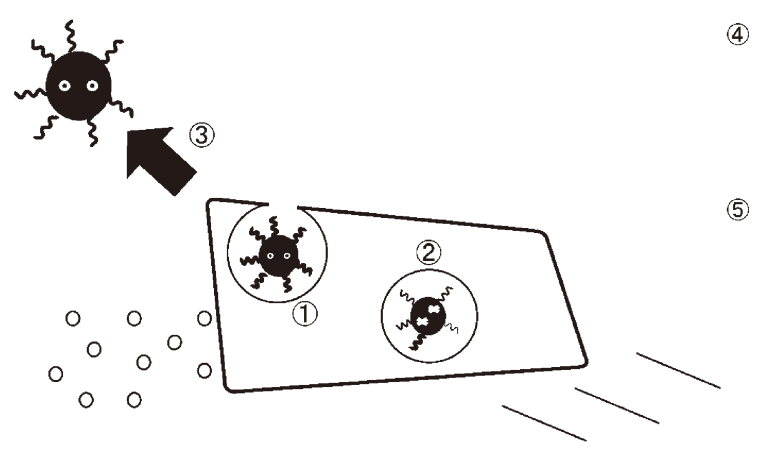

(4)

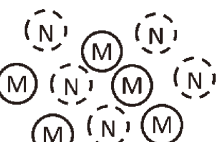

(5)

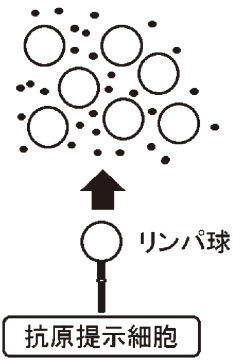

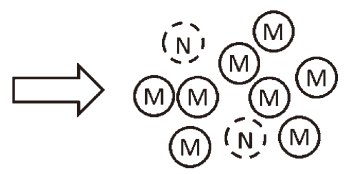
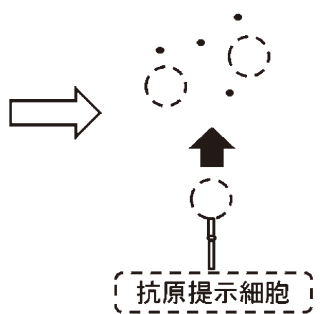

図 2 Immunosenescence

(1)貪食能の低下, (2)細胞内殺菌能の低下, (3)遊走能の低下, (4)ナイーヴ T リンパ球の減少, (5) リ パ球の活性化能低下 


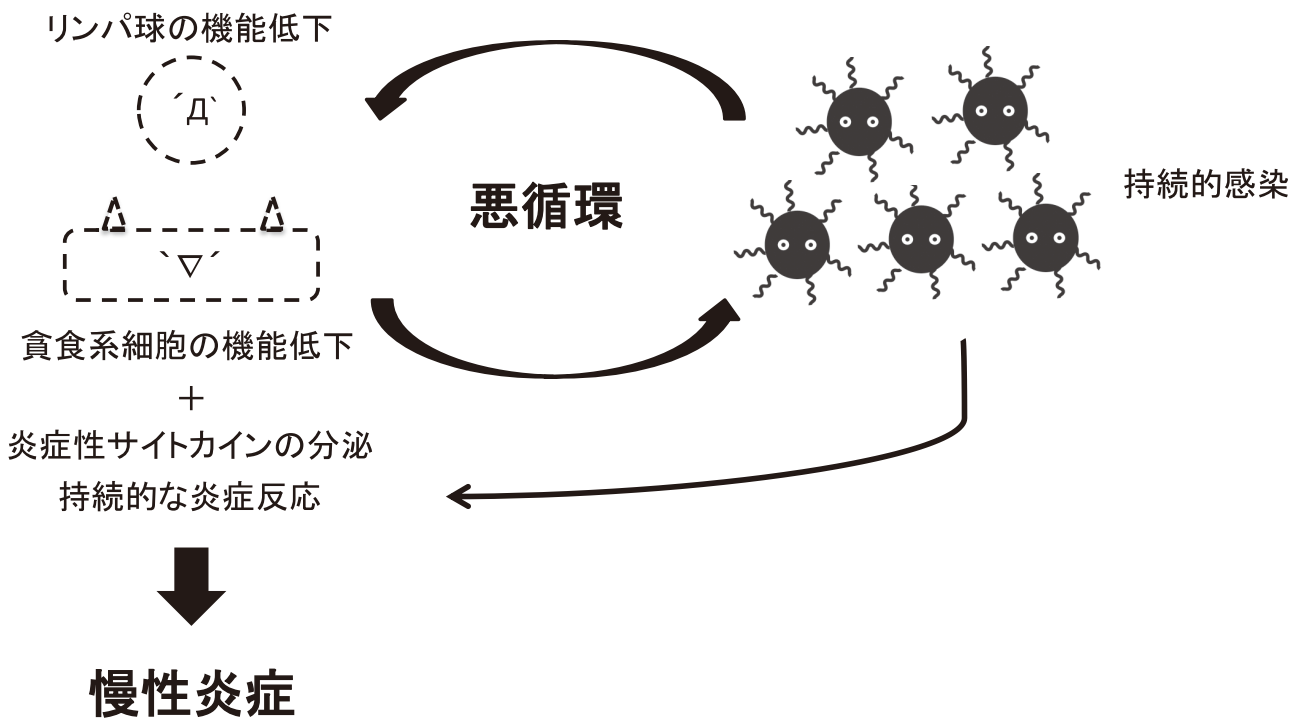

図 3 Inflammaging

リンパ球や貪食系細胞の機能低下により病原体や死細胞の除去が不十分になるとともに, 貪 食系細胞による炎症性サイトカインの分泌に異常が生じ，慢性炎症が起こる。

典的な補体経路を活性化することで感染防御に重要 な役割を果たすだけでなく, DNA や phosphatidylserine, calreticulin などの自己分子と結合して補体経 路非依存性に領食作用を促進することで組織のホメ オスタシスの維持にも働く多機能なタンパク質であ ることも明らかになってきている20).

\section{老化と Wnt シグナル活性化}

2007 年, スタンフォード大学の Rando らは，若 年マウスと老齢マウスの併体結合実験を通じて老齢 マウスの血中には若年マウスの組織に作用して老化 の表現型を誘導する液性因子が存在すること，その 液性因子が Wnt シグナルの共役受容体である Frizzled $(\mathrm{Fz})$ に結合し，Wnt シグナルを活性化させる分 子であることを報告した $(\text { 図 4 })^{21)}$ ，われわれは当時， 心筋細胞発生におけるWnt シグナルの役割に関する 研究を行っていたが，心血管疾患におけるWnt シ グナルの関与について検討も行っており，心不全モ デルマウスから採取した血清が高い Wnt シグナル活 性化能を有していることを見出していた。そこで心 不全モデルマウスで増加する Fz 結合分子を質量分 析で解析したところ補体分子 $\mathrm{C} 1 \mathrm{q}$ が同定された ${ }^{22)}$. また C1q は Fzに結合し, Wnt シグナルのもう一つ の共役受容体である LRP5/6の細胞外ドメインが C1s によって切断されることで Wnt シグナルが活性化
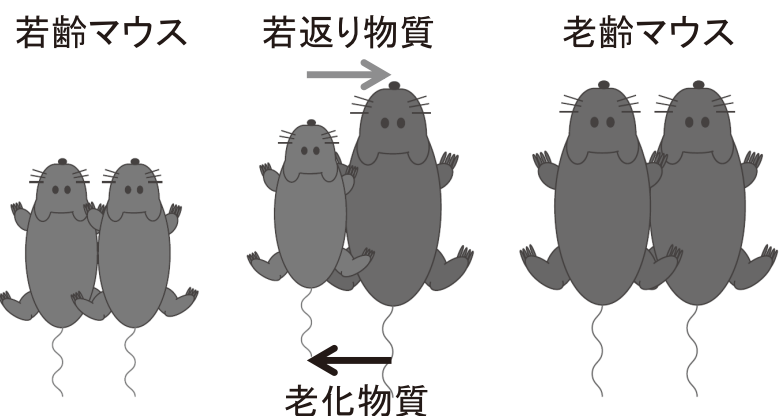

॥

\section{Wntシグナル活性化物質}

図 4 血中の老化誘導物質は Wnt シグナルを活性化する 若齢マウスと老齢マウスを結合した後，骨格筋に凍結障 害を加えると若齢マウスの骨格筋再生能は低下し，老齢 マウスの骨格筋再生能は回復する。また Wnt シグナルの 阻害剂を全身に投与することで，この作用は消失するこ とから Wnt シグナルを活性化する血中液性因子が老化を 誘導することが考えられた。

されることを見出した。補体分子 $\mathrm{C} 1 \mathrm{q}$ が加齢によ り血中で増加することや，加齢に伴って各組織にお いて発現が増加することは既に報告されていたこと から, 加齢に伴って血中で増加し，Wnt シグナル活 性化を介して老化を誘導する因子としての C1q の 可能性について解析を進めた。

\section{老化と C1q-Wnt シグナル}

加齢に伴って障害後の再生能が低下する一方，線 
維化が元進する。骨格筋においては衛生細胞という 骨格筋幹細胞の機能が加齢によって低下することが 知られている。衛生細胞を $\mathrm{C} 1 \mathrm{q}$ や Wnt タンパクで 刺激することで増殖能が低下する一方で骨格筋から 単離した線維芽細胞を $\mathrm{C} 1 \mathrm{q}$ や Wnt タンパクで刺激 すると増殖能の无進とコラーゲン産生増加が認めら れた。また，若年マウスの骨格筋に凍結障害を加え た後に C1q を作用させることで Wnt シグナルの活性 化とれ，再生能低下㧍よび線維化立進が認められる 一方，老齢マウスの骨格筋に凍結障害を加えた後に， $\mathrm{C} 1 \mathrm{~s}$ に対する中和抗体を作用させることで加齢に伴 う再生能低下と線維化充進を防ぐことができること から C1q が Wnt シグナルを介して加齢に伴う再生 能低下と線維化元進を制御している可能性が明らか になった。さらに $\mathrm{C} 3$ 欠損マウスでは野生型マウス と同様の加齢に伴う再生能低下と線維化光進を認め る一方, $\mathrm{C} 1 \mathrm{q}$ 欠損マウスでは加齢に伴う変化が小さ いことから，C1qによる老化制御は補体経路非依存 性であることが示された(図 5)。

\section{3. おわりに}

加齢に伴う免疫機能の低下は逆説的に慢性炎症を 引き起こす。慢性炎症の結果血中に増加する炎症性 タンパクである補体分子 $\mathrm{C} 1 \mathrm{q}$ は加齢に伴う再生能 低下を引き起こす原因の一つになっており，慢性炎 症を制御することで個体全体の老化を予防できる可 能性がある。一方, 加齢に伴う慢性炎症の背景には 加齢に伴う免疫能低下が存在しており, 慢性炎症を 安易に抑制するのではなく加齢に伴って免疫系の アンバランスをもたらす老化シグナルを補正するこ とで免疫機能のバランスをとるようなアプローチが 重要なのではないかと考えられる。

著者の利益相反 (COI)の開示 :

共同研究(第一三共株式会社, 小野薬品工業株式会 社)

\section{文献}

1) Plowden J, Renshaw-Hoelscher M, Engleman C, Katz J, Sambhara S: Innate immunity in aging: impact on macrophage function. Aging Cell 3: 161-167, 2004.

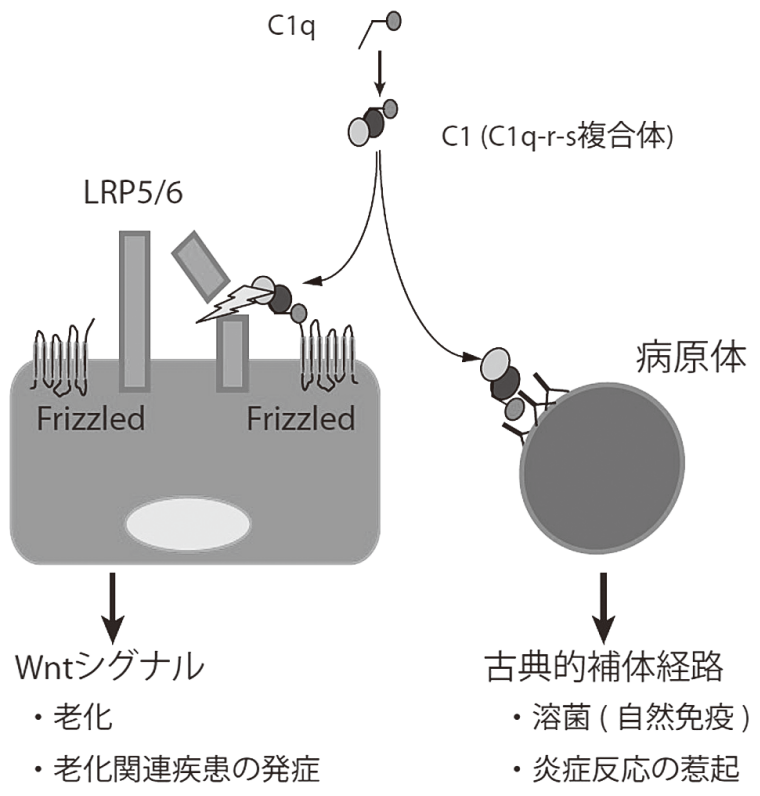

図 $5 \mathrm{C} 1 \mathrm{q}$ の新たな作用

C1q は古典的補体経路を通じて自然免疫系において重要 な役割を果たす。加齢に伴う慢性炎症によって持続的に C1q が増加する結果, Wnt シグナルの持続的な活性化が 起こり，老化現象の一つである骨格筋の再生能低下を引 き起こす

2) Wenisch C, Patruta S, Daxböck F, Krause R, Hörl W: Effect of age on human neutrophil function. J Leukoc Biol 67: 4045, 2000.

3) Kurban RS, Bhawan J: Histologic changes in skin associated with aging. J Dermatol Surg Oncol 16: 908-914, 1990.

4) Thiers BH, Maize JC, Spicer SS, Cantor AB: The effect of aging and chronic sun exposure on human Langerhans cell populations. J Invest Dermatol 82: 223-226, 1984.

5) Linton PJ, Dorshkind K: Age-related changes in lymphocyte development and function. Nat Immunol 5: 133-139, 2004.

6) Miller RA: The aging immune system: primer and prospectus. Science 273: 70-74, 1996.

7) Hale JS, Boursalian TE, Turk GL, Fink PJ: Thymic output in aged mice. Proc Natl Acad Sci U S A 103: 8447-8452, 2006.

8) Lazuardi L, Jenewein B, Wolf AM, Pfister G, Tzankov A, Grubeck-Loebenstein B: Age-related loss of naïve T cells and dysregulation of T-cell/B-cell interactions in human lymph nodes. Immunology 114: 37-43, 2005.

9) Garcia GG and Miller RA: Single-cell analyses reveal two defects in peptide-specific activation of naive $T$ cells from aged mice. J Immunol (Baltimore, Md. : 1950) 166: 31513157, 2001.

10) Engwerda CR, Fox BS and Handwerger BS: Cytokine production by $\mathrm{T}$ lymphocytes from young and aged mice. J Immunol (Baltimore, Md. : 1950) 156: 3621-3630, 1996.

11) Ferrucci L, Corsi A, Lauretani F, Bandinelli S, Bartali B, Taub DD, Guralnik JM, and Longo DL: The origins of age-related 
proinflammatory state. Blood 105: 2294-2299, 2005.

12) Paolisso G, Rizzo MR, Mazziotti G, Tagliamonte MR, Gambardella A, Rotondi M, Carella C, Giugliano D, Varricchio $\mathrm{M}$, and D'Onofrio $\mathrm{F}$ : Advancing age and insulin resistance: role of plasma tumor necrosis factor-alpha. Am J Physiol 275: E294-E299, 1998.

13) Nagaki K, Hiramatsu S, Inai S, Sasaki A: The effect of aging on complement activity (CH50) and complement protein levels. J Clin Lab Immunol 3: 45-50, 1980.

14) Romani L, Fallarino F, De Luca A, Montagnoli C, D'Angelo C, Zelante T, Vacca C, Bistoni F, Fioretti MC, Grohmann U, Segal BH, and Puccetti P: Defective tryptophan catabolism underlies inflammation in mouse chronic granulomatous disease. Nature 451: 211-215, 2008.

15) Wang H, Peters $T$, Kess D, Sindrilaru A, Oreshkova T, Van Rooijen N, Stratis A, Renkl AC, Sunderkotter C, Wlaschek M, Haase I, and Scharffetter-Kochanek K: Activated macrophages are essential in a murine model for $\mathrm{T}$ cell-mediated chronic psoriasiform skin inflammation. J Clin Invest 116: 2105-2114, 2006.

16) Deeks SG: HIV infection, inflammation, immunosenescence, and aging. Annu Rev Med 62: 141-155, 2011.

17) Koch S, Larbi A, Ozcelik D, Solana R, Gouttefangeas C, Attig S, Wikby A, Strindhall J, Franceschi C, and Pawelec G: Cytomegalovirus infection: a driving force in human $\mathrm{T}$ cell immunosenescence. Ann N Y Acad Sci 1114: 23-35, 2007.
18) Olsson J, Wikby A, Johansson B, Lofgren S, Nilsson BO, and Ferguson FG: Age-related change in peripheral blood T-lymphocyte subpopulations and cytomegalovirus infection in the very old: the Swedish longitudinal OCTO immune study. Mech Ageing Dev 121: 187-201, 2000.

19) Szalai AJ, Agrawal A, Greenhough TJ, Volanakis JE: C-reactive protein: structural biology and host defense function. Clin Chem Lab Med 37: 265-270, 1999.

20) Païdassi H, Tacnet-Delorme P, Verneret M, Gaboriaud C, Houen G, Duus K, Ling WL, Arlaud GJ, Frachet P: Investigations on the $\mathrm{C} 1 \mathrm{q}$-calreticulin-phosphatidylserine interactions yield new insights into apoptotic cell recognition. J Mol Biol 408: 277-290, 2011.

21) Liu H, Fergusson MM, Castilho RM, Liu J, Cao L, Chen J, Malide D, Rovira, II, Schimel D, Kuo CJ, Gutkind JS, Hwang PM, and Finkel T: Augmented Wnt signaling in a mammalian model of accelerated aging. Science (New York, N.Y.) 317: 803-806, 2007.

22) Naito AT, Sumida T, Nomura S, Liu ML, Higo T, Nakagawa A, Okada K, Sakai T, Hashimoto A, Hara Y, Shimizu I, Zhu W, Toko H, Katada A, Akazawa H, Oka T, Lee JK, Minamino T, Nagai T, Walsh K, Kikuchi A, Matsumoto M, Botto M, Shiojima I, and Komuro I: Complement C1q activates canonical Wnt signaling and promotes aging-related phenotypes. Cell 149: 1298-1313, 2012. 